Original Article

\title{
Use of multi-strain probiotics in linseed meal based diet for Labeo rohita fingerlings
}

\author{
Uso de probióticos multi-cepas na dieta à base de farinha de linhaça para alevinos de \\ Labeo rohita
}

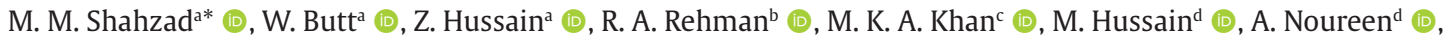

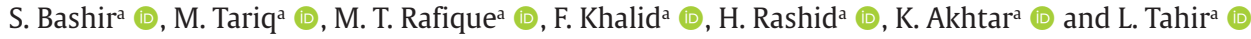 \\ aUniversity of Education, Division of Science and Technology, Department of Zoology, Lahore, Pakistan \\ bUniversity of Health Sciences Lahore, Department of Forensic Sciences, Lahore, Pakistan \\ 'University of Okara, Department of Zoology, Okara, Pakistan \\ dUniversity of Lahore, Institute of Molecular Biology and Biotechnology, Lahore, Pakistan
}

\begin{abstract}
Unavailability of probiotics in fish digestive system fingerlings is unable to digest and absorb their food properly. The current research was conducted to investigate the influence of probiotics added Linseed meal based (LMB) diet on hematology and carcass composition of Labeo rohita juveniles. Hematological parameters are essential diagnostics used to estimate the health status of fish. The usage of probiotics for fish health improvement is becoming common due to the higher demand for environment-friendly culture system in water. Linseed meal was used as a test ingredient to prepare six experimental test diets by adding probiotics $(0,1,2,3,4$ and $5 \mathrm{~g} / \mathrm{kg})$ and $1 \%$ indigestible chromic oxide for seventy days. According to their live wet weight, five percent feed was given to fingerlings twice a day. Fish blood and carcass samples (Whole body) were taken for hematological and carcass analysis at the end of the experiment. The highest carcass composition (crude protein; $18.72 \%$, crude fat; $8.80 \%$ and gross energy; $2.31 \mathrm{kcal} / \mathrm{g}$ ) was observed in fish fed with test diet II supplemented with probiotics $(2 \mathrm{~g} / \mathrm{kg})$. Moreover, maximum RBCs number $\left(2.62 \times 10^{6} \mathrm{~mm}^{-3}\right)$, WBCs $\left(7.84 \times 10^{3} \mathrm{~mm}^{-3}\right), \mathrm{PCV}(24.61)$, platelets (63.85) and hemoglobin (7.87) had also been reported in the fish fingerlings fed on $2 \mathrm{~g} / \mathrm{kg}$ of probiotics supplemented diet. Results indicated that probiotics supplementation has a critical role in improvement of fingerlings' body composition and hematological indices. Present findings showed that probiotics supplementation at $2 \mathrm{~g} / \mathrm{kg}$ level in linseed by-product-based diet was very useful for enhancing the overall performance of $L$. rohita fingerlings.
\end{abstract}

Keywords: LMB, hematology, probiotics, carcass composition.

\begin{abstract}
Resumo
A indisponibilidade de probióticos em alevinos do sistema digestivo de peixes faz com que ele seja incapaz de digerir e absorver seus alimentos adequadamente. A presente pesquisa foi conduzida para investigar a influência de probióticos adicionados à dieta à base de farelo de linhaça (LMB) na hematologia e na composição da carcaça de juvenis de Labeo rohita. Os parâmetros hematológicos são diagnósticos essenciais usados para estimar o estado de saúde dos peixes. O uso de probióticos para a melhoria da saúde dos peixes está se tornando comum devido à maior demanda por sistemas de cultivo em água que não agridam o meio ambiente. Farinha de linhaça foi usada como ingrediente para preparar seis dietas de teste experimentais adicionando probióticos $(0,1,2,3,4$ e $5 \mathrm{~g} / \mathrm{kg}) \mathrm{e}$ $1 \%$ de óxido crômico indigestível por 70 dias. De acordo com seu peso úmido vivo, $5 \%$ de alimento eram dados aos alevinos duas vezes ao dia. Amostras de sangue e carcaça de peixes (corpo inteiro) foram coletadas para análise hematológica e de carcaça no final do experimento. A maior composição da carcaça (proteína bruta, 18,72\%; gordura bruta, 8,80\%; e energia bruta, 2,31 kcal $/ \mathrm{g}$ ) foi observada em peixes alimentados com a dieta teste II suplementada com probióticos $(2 \mathrm{~g} / \mathrm{kg})$. Além disso, os números máximos de RBCs $\left(2,62 \times 106 \mathrm{~mm}^{-3}\right)$, WBCs $\left(7,84 \times 103 \mathrm{~mm}^{-3}\right), \mathrm{PCV}$ $(24,61)$, plaquetas $(63,85)$ e hemoglobina $(7,87)$ também foram relatados em alevinos alimentados com $2 \mathrm{~g} / \mathrm{kg}$ de dieta suplementada com probióticos. Os resultados indicaram que a suplementação de probióticos tem um papel crítico na melhoria da composição corporal dos alevinos e índices hematológicos. As descobertas atuais mostraram que a suplementação de probióticos no nível de $2 \mathrm{~g} / \mathrm{kg}$ em dieta à base de subproduto de linhaça foi muito útil para melhorar o desempenho geral de alevinos de $L$. rohita.
\end{abstract}

Palavras-chave: LMB, hematologia, probióticos, composição de carcaça.

*e-mail: drmudassarshahzad@gmail.com

Received: December 17, 2020 - Accepted: March 1, 2021 


\section{Introduction}

Aquaculture is one of the prime food sectors worldwide that represents the novel source of animal protein for the constantly growing population (Dawood and Koshio, 2016). World output in 2012 included 91.3 million tons of commercial fishing in the wild and 158 million tons by aquaculture (FAO, 2015). World aquaculture fish production was $31.1 \%$ in $2004,42.1 \%$ in 2012 and in 2014 was $44.1 \%$, making aquaculture the world's fastest-growing food sector (FAO, 2016).

In aquaculture, fish meal (FM) is a chief source of animal protein, enriched with nutrients i.e. amino acid, vitamins, essential fatty-acids, minerals etc. (Zhou et al., 2004). FM has been served as the significant protein source in aqua feed of carnivorous fish, which tends to possess higher dietary protein requirements (Hardy, 2010; Kumar et al., 2008; Wang et al., 2015). Increasing demands and decreased accessibility with higher cost (about $220 \mathrm{PKR} / \mathrm{kg}$ ) of the FM pushed the idea to explore other protein sources in fish culture (Pham et al., 2008; Shahzad et al., 2021). Therefore, it is important to explore cost-effective and locally available alternative source of protein for fish feed (Saad, 1979).

In fish diet, plant by-products are the excellent replacer (Liu et al., 2013), and are more economical than FM. Therefore, the substitution of FM with plant by-products is often recommended. Due to the high protein value (Reigh and Ellis, 1992), soybean, cottonseed, Moringa and canola meal were often suggested as possible elective fish feed (Shahzad et al., 2020). In Egypt, the linseed widely called 'Ketan' is commonly grown and considered an oil plant. China is expected to produce approximately $22 \%$ of linseed oil (Li et al., 2016). After oil extraction, the by-product known as linseed meal (about $40 \mathrm{PKR} / \mathrm{kg}$ ) is used particularly in rural areas to feed young cows and calves. There is less detail on the use of linseed as an origin of protein in feeds for aquatic animals. Therefore, this research is conducted to assess the viability of linseed meal as a potential partial and total substitute of FM protein in diets for $L$. rohita fingerlings.

L. rohita is generally called Rohu and is cultivated in Asia, mainly in the Indian subcontinent (Khan et al., 2004). It is an inhabitant of the Indo-Gangetic river and raised successfully across northern and central rivers in Pakistan (Reddy, 1999). Among seven fish species that are most prominent, delicious, have great development rate and higher growth on a prepared diet. It also reaches the mark-able size of 800-1000 g in one year. (Khan et al., 2008; Hussain et al., 2011). Due to its numerous great properties and market preference, this fish's cultivation has been increased in recent years (Khan et al., 2004).

Due to high market demand, the stocking culture of L. rohita leads to stress (Wang et al., 2015). Stress affects fish's health and contributes to immunosuppression and increased infectious diseases (Awad and Awaad, 2017; Aliko et al., 2018; Gobi et al., 2018). Pathogenic organisms are commonly responsible for disease outbreaks and belong to the genera; Aeromonas, Vibrio, Edwardsiella, Pseudomonas and Streptococcus. Infection more often occurs in the gastric tract of fish (Sugita et al., 1996;
Defoirdt et al., 2011). These pathogenic bacteria usually cause ulcerations of skin, gills, opercula, tail and blade spoil, dropsy and hemorrhagic septicemia in fish (Austin and Austin, 2007; Kaleeswaran et al., 2011). For the control of these infections, chemical substances and anti-microbials have been introduced (Guardiola et al., 2016; Aliko et al., 2018). However, anti-infection agents are very expensive, and these compounds' utilization also provokes numerous issues (Zhou et al., 2010).

Thus, to cope all these problems, probiotics have been used in aquaculture. It is characterized as "live microbial feed supplement which when administered in sufficient amount, advantageously influences the host by improving microbial balance" (Fuller Afrc, 1989). Extra advantages of probiotics in aquaculture include optimizing the quality of water, health of host species through the production of digestive enzymes, efficient removal of harmful pathogens, increased survival rates and disease resistance (Verschuere et al., 2000). Probiotics are, therefore a good strategy for managing microbial diseases with great potential by replacement of antibiotics. It has been noticed that probiotic mixtures are more efficient in disease control than a single culture (Aly et al., 2008; Ridha and Azad, 2016). Additionally, information about the impact of probiotics on rohu immune system morphology is sparsely present. Therefore, the present study was planned to assess the efficacy of probiotics supplements on the hematology and body composition of $L$. rohita fed on a linseed by-products-based diet.

\section{Materials and Methods}

\subsection{Experimental conditions}

Study was conducted under the rules and regulations issues by ethical committee of the university to estimate the impacts of probiotics-supplemented linseed by-product based diet on hematology and proximate composition of L. rohita fingerlings.

Fingerlings of $L$. rohita were purchased from Manawa Fish seed Hatchery, Lahore and were kept in fish tanks (V shape) with a $70 \mathrm{~L}$ water capacity. Before the start of the experiment, fingerlings were acclimatized to the laboratory condition for fourteen days. During the acclimatization period, fish were fed once a day on the basal diet (Rowland, 1991). Water quality parameters such as dissolved oxygen (DO), $\mathrm{pH}$, and temperature were recorded daily. The oxygen pump was used throughout the study period to supply oxygen from the capillary system. Before the experimental research began, fingerlings were treated with $0.5 \%$ saline solution for 1 to 2 minutes to kill the pathogens (Rowland and Ingram, 1991).

\subsection{Experimental design}

Linseed was used as a test diet and major feed element. One control and five test diets supplemented with graded levels $(1,2,3,4$ and $5 \mathrm{~g} / \mathrm{kg})$ of probiotics $\left(1 \mathrm{~g}=2 \times 10^{9} \mathrm{CFU}\right)$ were prepared. Five probiotics supplemented and one control LMB diet was given to six groups of fish, stocked in triplicate water tanks, each with 15 fingerlings. 
Total feeding trial duration was conducted following a completely randomized design (CRD) for seventy days period. Probiotics supplemented diets were compared with each other and control diet to analyze hematology and carcass composition of fish.

\subsection{Pellet formation}

Feed ingredients for the experimental diet were bought from the local market (Table 1). The chemical composition of the diet was tested by using standard methods (AOAC, 1995 ) before the experimental diet formulation. As an inert marker, chromic oxide (1\%) was introduced. All feed constituents were blended for 10-15 (ten to fifteen) minutes and fish oil was added slowly. During this, 10-15\% distilled $\mathrm{H}_{2} \mathrm{O}$ was supplemented to prepare the required texture and feed pellet were prepared. All diets have been supplemented with the set percentages of probiotics, except control diet (with no probiotics supplementation) and stored at $4{ }^{\circ} \mathrm{C}$ until use after drying.

\subsection{Analysis of hematological parameters}

After 70 days of the experiment, three fish from each tank were selected to collect blood samples and anaesthetized with $150 \mathrm{~m} / \mathrm{g}$ methane-sulfonate solution (Wagner et al., 1997). Blood samples were obtained from the caudal vein by heparinized syringe and taken to the laboratory to analyze hematological indices. For the determination of hematocrit, micro- hematocrit technique was used (Brown, 1980). RBCs and WBCs were calculated on an appropriate chamber for Neubauer counting haemocytometer (Blaxhall and Daisley, 1973). The hemoglobin (Hb) was estimated by a method used by Wedemeyer and Yasutake (1977). Whereas, MCV (mean cell volume), MCHC (mean corpuscular hemoglobin concentration) and $\mathrm{MCH}$ (mean corpuscular hemoglobin) were measured by using following Formula 1, 2 and 3:

$$
\begin{aligned}
& M C V=P C V / R B C \times 10 \\
& M C H=H b / R B C \times 10 \\
& M C H C=H b / P C V \times 10
\end{aligned}
$$

\subsection{Analysis of immunological parameters}

For the examination of immunological parameters, blood samples were obtained without anticoagulant. For the determination of erythrocytes and leucocytes, blood sample smears were prepared. Lymphocytes, eosinophil, monocytes and neutrophils were counted with Neubauer differential counting method. The centrifugation method was used for the separation of serum samples, and these samples were stored in a freezer at $-20{ }^{\circ} \mathrm{C}$ until analysis.

\subsection{Chemical analysis of carcass composition}

Fish (three) were randomly selected from each replicate and sacrificed using standard methods to analyze carcass composition (AOAC, 1995). With oxygen-bomb-calorimeter, gross energy in the whole body was assessed. The crude protein was analyzed by Micro Kjeldahl apparatus.

\begin{tabular}{|c|c|c|c|c|c|c|c|c|}
\hline \multirow[b]{2}{*}{ Ingredients } & \multirow{2}{*}{$\begin{array}{l}\text { Composition } \\
\text { of Test Diets }\end{array}$} & \multicolumn{7}{|c|}{ Chemicals Composition of Feed components (\%) } \\
\hline & & $\begin{array}{l}\text { Dry Matter } \\
(\%)\end{array}$ & $\underset{(k c a l / g)}{G E}$ & $\begin{array}{l}\text { CP } \\
\text { (\%) }\end{array}$ & $\begin{array}{l}\text { EE } \\
(\%)\end{array}$ & $\begin{array}{l}\text { CF } \\
\text { (\%) }\end{array}$ & $\begin{array}{c}\text { Ash } \\
\text { (kcal/g) }\end{array}$ & $\begin{array}{c}\text { Carbohydrates } \\
\text { (\%) }\end{array}$ \\
\hline Linseed meal & & 92.41 & 3.86 & 33.78 & 6.83 & 2.76 & 6.51 & 50.12 \\
\hline Fish meal & 13 & 91.93 & 3.92 & 45.13 & 8.46 & 1.7 & 21.53 & 23.18 \\
\hline Wheat flour & 13 & 91.81 & 2.8 & 9.69 & 2.27 & 2.68 & 3.49 & 81.87 \\
\hline Sunflower & 14 & 92.03 & 4.11 & 32.68 & 5.74 & 2.54 & 2.43 & 56.61 \\
\hline Rice polish & 12 & 93.59 & 4.08 & 13.59 & 10.09 & 3.9 & 6.83 & 65.59 \\
\hline Fish oil & 9 & - & - & - & - & - & - & - \\
\hline $\begin{array}{l}\text { Mineral } \\
\text { Premix }\end{array}$ & 1 & - & - & - & - & - & - & - \\
\hline $\begin{array}{l}\text { Vitamin } \\
\text { Premix }\end{array}$ & 1 & - & - & - & - & - & - & - \\
\hline $\begin{array}{l}\text { Chromic } \\
\text { oxide }\end{array}$ & 1 & - & - & - & - & - & - & - \\
\hline Ascorbic acid & 1 & - & - & - & - & - & - & - \\
\hline Probiotics ${ }^{* * *}$ & $0-5 \mathrm{~g} / \mathrm{kg}$ & - & - & - & - & - & - & - \\
\hline
\end{tabular}
The moisture content of the carcass was measured by

Table 1. Ingredients' composition (\%) and chemical composition (\%) of LMB test diet for L. rohita fingerlings.

*** L. acidophilus, L. rhamnosus, B. lactis, B. bifidum, Bifidobecterium, S. thermophiles, L. bulgaricus; $* *$ Vitamin $\mathrm{B}_{1}=3000 \mathrm{mg} ; \mathrm{Vitamin} \mathrm{E}=30000 \mathrm{IU}$; Vitamin $B_{2}=7000 \mathrm{mg}$; Vitamin $B_{6}=4000 \mathrm{mg}$; Vitamin $B_{12}=40 \mathrm{mg} ;$ Vitamin $\mathrm{D}_{3}=3,000,000 \mathrm{IU} ;$ Vitamin C=15,000 mg; Vitamin K $=8000 \mathrm{mg} ;$ Vitamin $\mathrm{A}=15,000,000 \mathrm{IU}$; Calcium pantothenate $=12,000 \mathrm{mg} ;$ Folic acid = $1500 \mathrm{mg}$; Nicotinic acid = 60,000 mg; $* \mathrm{Manganese}=2000 \mathrm{mg} ;$ Sodium = 45 g; Zinc = $3000 \mathrm{mg} ;$ Calcium = $155 \mathrm{~g} ;$ Copper = $600 \mathrm{mg} ;$ Iron = $1000 \mathrm{mg} ;$ Cobalt = 40 mg; Iodine = 40 mg; Phosphorus = $135 \mathrm{~g} ;$ Magnesium = 55 g; Selenium = $3 \mathrm{mg}$. GE stands for Gross Energy, CP stands for Crude Protein, EE stands for Ether Extract and CF stands for Crude fiber. 
oven drying the sample at $105^{\circ} \mathrm{C}$ for 12 hours. Petroleum ether extraction method through Soxtec system was used to analyze the crude fat while, crude fibre was determined after digestion with $1.25 \% \mathrm{H}_{2} \mathrm{SO}_{4}$ and $1.25 \% \mathrm{NaOH}$, as a loss on ignition of dried lipid-free residues. Ash was determined at $650{ }^{\circ} \mathrm{C}$ for 12 hours at constant heat in the electric furnace (Eyela-TMF 3100) Total carbohydrates were calculated using the following Formula 4.

$$
\text { Total carbohydrates }(\%)=\left(\begin{array}{l}
100-\text { moisture }+ \text { protein } \%+ \\
\text { fat } \%+\text { crude fibre } \%+\text { Ash }
\end{array}\right)
$$

\subsection{Statistical analysis}

Data on the composition of carcass and fish hematology was subjected to one-way ANOVA. Variations between means were compared using the Honesty Significant Difference Test by Tukey and were considered significant at $p<0.05$ (Snedecor and Cochran, 1991). For statistical analysis, the CoStat computer software (Version 6.303, PMB 320, and Monterey, CA, 93940 USA) was used.

\section{Results}

The hematological parameters of L. rohita fed on probiotics supplemented linseed by-product based diet are summarized in Table 2. Analysis for hematological parameters revealed variations in fish fed on probiotics supplemented test diets and control diet. From the results, it was found that when fingerlings fed with test diet $2(2 \mathrm{~g} / \mathrm{kg}$ of probiotics $)$ had the highest RBCs $\left(2.62 \times 10^{6} \mathrm{~mm}^{-3}\right)$, hemoglobin ( $7.87 \mathrm{~g} / 100 \mathrm{~mL})$, PCV (24.61\%) and PLTs count (63.85). These values are statistically different from control and other test diets. Lowest RBCs count $\left(1.12 \times 10^{6} \mathrm{~mm}^{-3}\right)$, Hb $(5.70 \mathrm{~g} / 100 \mathrm{~mL})$ and PCV (21.13\%) were observed in fish fed at test diet 5 ( $5 \mathrm{~g} / \mathrm{kg}$ of probiotics level), whereas lowest PLTs count (52.64) was observed in fish fed on control diet $(0 \mathrm{~g} / \mathrm{kg}$ of probiotics). $\mathrm{MCHC}(33.90 \%)$ and $\mathrm{Ht}$ (31.31\%) were highest in fish fed at test diet 3 ( $3 \mathrm{~g} / \mathrm{kg}$ of probiotics), while the lowest MCHC (29.59\%) and Ht (24.69\%) were found in fish fed on test diet 5 ( $5 \mathrm{~g} / \mathrm{kg}$ probiotics $)$ and control diet respectively. Maximum values of $\mathrm{MCH}(48.64 \mathrm{pg})$ and $\mathrm{MCV}$ (167.67fl) were noted in fingerlings when fed at $4 \mathrm{~g} \mathrm{~kg}^{-1}$ of probiotics. On the other hand, minimum values of $\mathrm{MCH}$ (37.85\%) and MCV (93.50fl) were observed when fingerlings were fed with test diet 1 ( $1 \mathrm{~g} / \mathrm{kg}$ probiotics level) while, second-lowest values of MCH(40.31) and MCV (99.60) were observed at control diet. These results were significantly dissimilar from each other (Figure 1). These results showed that L. rohita fingerlings' hematological parameters improved with the addition of probiotics in linseed by-product-based diet. Hematological parameters improved with increased level of probiotics up to $2 \mathrm{~g} / \mathrm{kg}$ of probiotics and decreased after it, as shown in Table 2. Hence it was concluded that $2 \mathrm{~g} / \mathrm{kg}$ was the optimum value of probiotics that significantly increases the hemato-immunity of $L$. rohita fingerlings.

Table 2. Hematological parameters of L. rohita fingerlings fed with probiotics supplemented linseed by-product based diet.

\begin{tabular}{|c|c|c|c|c|c|c|c|c|c|}
\hline Test Diets & $\begin{array}{c}\text { Probiotics } \\
\text { Level (g/kg) }\end{array}$ & $\begin{array}{c}\mathrm{RBC}\left(10^{6}\right. \\
\left.\mathrm{mm}^{-3}\right)\end{array}$ & $\begin{array}{c}\mathrm{Hb}(\mathrm{g} / 100 \\
\mathrm{mL})\end{array}$ & PCV (\%) & MCHC (\%) & MCH (pg) & $\operatorname{MCV}(f 1)$ & Ht \% & PLT \\
\hline $\begin{array}{c}\text { Control } \\
\text { diet }\end{array}$ & 0 & $1.30 \pm 0.16^{c}$ & $5.96 \pm 0.76^{b}$ & $24.02 \pm 0.45^{\mathrm{ab}}$ & $31.29 \pm 0.89^{b c}$ & $40.31 \pm 0.43^{c}$ & $99.60 \pm 0.92^{\mathrm{e}}$ & $24.69 \pm 0.60^{c}$ & $52.64 \pm 0.94^{c}$ \\
\hline Test diet 1 & 1 & $2.07 \pm 0.14^{\mathrm{b}}$ & $7.00 \pm 0.39^{\mathrm{ab}}$ & $24.05 \pm 0.32^{\mathrm{ab}}$ & $31.99 \pm 0.52^{\mathrm{b}}$ & $37.85 \pm 0.56^{\mathrm{d}}$ & $93.50 \pm 0.62^{f}$ & $30.98 \pm 0.81^{\mathrm{a}}$ & $61.56 \pm 0.74^{a}$ \\
\hline Test diet 2 & 2 & $2.62 \pm 0.22^{\mathrm{a}}$ & $7.87 \pm 0.40^{\mathrm{a}}$ & $24.61 \pm 0.92^{\mathrm{a}}$ & $32.89 \pm 0.65^{\mathrm{ab}}$ & $44.29 \pm 0.60^{\mathrm{b}}$ & $144.89 \pm 0.58^{\mathrm{d}}$ & $26.15 \pm 0.73^{\mathrm{bc}}$ & $63.85 \pm 0.92^{\mathrm{a}}$ \\
\hline Test diet 3 & 3 & $2.40 \pm 0.24^{\mathrm{ab}}$ & $7.35 \pm 0.36^{\mathrm{a}}$ & $23.66 \pm 0.46^{\mathrm{ab}}$ & $33.90 \pm 0.55^{\mathrm{a}}$ & $47.55 \pm 0.79^{a}$ & $165.47 \pm 0.82^{\mathrm{b}}$ & $31.31 \pm 0.97^{\mathrm{a}}$ & $62.53 \pm 1.18^{\mathrm{a}}$ \\
\hline Test diet 4 & 4 & $2.04 \pm 0.21^{\mathrm{b}}$ & $6.58 \pm 0.40^{\mathrm{ab}}$ & $22.91 \pm 0.35^{b}$ & $32.64 \pm 0.44^{\mathrm{ab}}$ & $48.64 \pm 0.94^{\mathrm{a}}$ & $167.67 \pm 0.94^{a}$ & $26.76 \pm 0.40^{\mathrm{b}}$ & $58.24 \pm 0.80^{\mathrm{b}}$ \\
\hline Test diet 5 & 5 & $1.12 \pm 0.18^{c}$ & $5.70 \pm 0.56^{\mathrm{b}}$ & $21.13 \pm 0.68^{c}$ & $29.59 \pm 0.77^{c}$ & $45.29 \pm 0.53^{b}$ & $148.18 \pm 0.82^{c}$ & $26.68 \pm 0.78^{c}$ & $57.14 \pm 0.91^{\mathrm{b}}$ \\
\hline
\end{tabular}

RBCs = Red blood cells; $\mathrm{Hb}=$ Hemoglobin concentration; PCV = Packed Cell Volume; MCHC = Mean Corpuscular Hemoglobin Concentration; $\mathrm{MCH}=$ Mean Corpuscular hemoglobin; MCV = Mean corpuscular Volume; Ht = Hematocrit; PLT = Platelets. Means in columns having dissimilar superscripts are statistically different at $\mathrm{p}<0.05$. Data are means of triplicates.

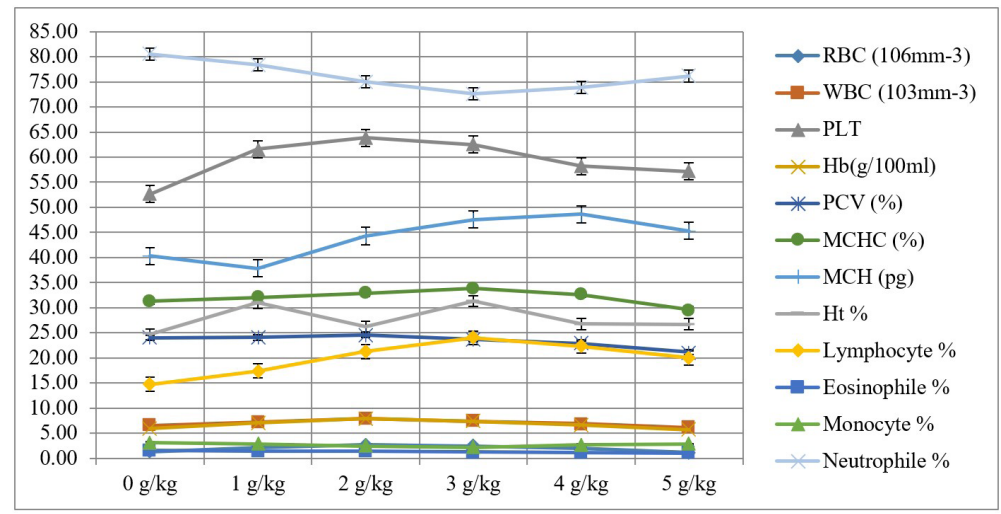

Figure 1. Cumulative hemato-immunological parameters of $L$. rohita fingerlings in different groups; T0 to T5. 
Table 3 showed results of immunological parameters of $L$. rohita fingerlings, fed with probiotics supplemented linseed by-product based diet. Immunological parameters included lymphocytes, eosinophil, monocytes and neutrophils. Highest count of WBCs $\left(7.84 \times 10 \mathrm{~mm}^{-3}\right)$ was observed in fish fed at test diet $2(2 \mathrm{~g} / \mathrm{kg}$ of probiotics $)$, followed by second highest value $\left(7.34 \times 10 \mathrm{~mm}^{-3}\right)$ at test diet $3(3 \mathrm{~g} / \mathrm{kg}$ of probiotics). Lowest value of WBCs $\left(6.10 \times 10 \mathrm{~mm}^{-3}\right)$ was observed at test diet $5(5 \mathrm{~g} / \mathrm{kg}$ of probiotics). Second lowest value of WBCs $\left(6.53 \times 10 \mathrm{~mm}^{-3}\right)$ was found in fish fed on the control diet. Fish fed on a control diet had the highest count of eosinophil (1.51\%), neutrophils (80.58\%) and Monocytes (3.18\%). In comparison, the lowest (1.04\%) value of eosinophil was noted in fish fed on test diet $5(5 \mathrm{~g} / \mathrm{kg}$ of probiotics $)$. On the other hand, the lowest count of monocytes (2.16\%) and neutrophils (72.63\%) was found in fish, fed on test diet 3 ( $3 \mathrm{~g} / \mathrm{kg}$ of probiotics). All these values were significantly different from each other. The highest count of lymphocytes (23.97\%) was recorded in fish fed on test diet $3(3 \mathrm{~g} / \mathrm{kg}$ of probiotics), followed by second highest (22.28\%) in fish fed on test diet $4(4 \mathrm{~g} / \mathrm{kg}$ of probiotics). Fish fed on control diet had lowest lymphocytes count (14.74\%). These variations in different groups showed the usage of probiotics in fish gut and body as well. There was no significant improvement in the immunological parameters of fish due to supplementations of probiotics. Results showed that, the control diet $(0 \mathrm{~g} / \mathrm{kg}$ of probiotics) significantly increases the immunological parameters of L. rohita fingerlings as compared to other test diets.

Table 4 showed the carcass composition of $L$. rohita fed with probiotics supplemented linseed by-product based diet. As compared to control diet, probiotics supplemented diets played a significant role in fish body composition by the retention of useful nutrients. Results showed that body composition of L. rohita improved with the additions of probiotics in diet. Results showed that maximum value of crude protein (18.72\%), crude fat $(8.80 \%)$ and gross energy $(2.31 \mathrm{kcal} / \mathrm{g}$ ) were found in fish fed on test diet $2(2 \mathrm{~g} / \mathrm{kg}$ of probiotics supplementations). Second highest level of crude protein (17.89\%) and crude fat $(8.38 \%)$ were found in the fish fed on test diet $3(3 \mathrm{~g} / \mathrm{kg}$ of probiotics) and gross energy $(2.20 \mathrm{kcal} / \mathrm{g})$ in test diet $1(1 \mathrm{~g} / \mathrm{kg}$ of probiotics). On the other hand, lowest value of CP (12.66\%) and crude fat (6.24\%) were recorded in test diet $5(5 \mathrm{~g} / \mathrm{kg}$ of probiotics) while gross energy $(1.14 \mathrm{kcal} / \mathrm{g})$ in test diet $5(5 \mathrm{~g} / \mathrm{kg}$ of probiotics). Ash, crude fibre (CF) and carbohydrate concentrations were closely similar in all diets. But, the highest ash $(5.94 \mathrm{kcal} / \mathrm{g})$ and carbohydrates value (2.76\%) were recorded in fish fed at test diet 3 ( $3 \mathrm{~g} / \mathrm{kg}$ of probiotics). On the other hand, lowest level of ash $(5.34 \mathrm{kcal} / \mathrm{g})$ was noted in fish of test diet $4(4 \mathrm{~g} / \mathrm{kg}$ of probiotics) and carbohydrates (2.37\%) in fish fed on test diet 5 ( $5 \mathrm{~g} / \mathrm{kg}$ of probiotics). All these values of ash and carbohydrates were non-significant to other diets. Maximum amount of crude fibre (1.25\%) was observed in fish fed with $3 \mathrm{~g} / \mathrm{kg}$ probiotics-added diet. Lowest crude fibre concentration $(1.02 \%)$ was found in fingerlings fed with test-diet $4(4 \mathrm{~g} / \mathrm{kg}$ of probiotics). Moisture content was highest (70.88\%) in fish fed on test diet $5(5 \mathrm{~g} / \mathrm{kg}$ of probiotics) while minimum (61.01\%) at test diet $2(2 \mathrm{~g} / \mathrm{kg}$ of probiotics). From the above mentioned results, it was concluded that $2 \mathrm{~g} / \mathrm{kg}$ of probiotics is the optimum level for enhancing nutrient retention in the body and improving the carcass composition of $L$. rohita as shown in Figure 2.

Table 3. Immunological parameters of $L$. rohita fingerlings fed with probiotics supplemented linseed by-product based diet.

\begin{tabular}{ccccccc}
\hline Diets & $\begin{array}{c}\text { Probiotics Level } \\
\left(\mathbf{g} / \mathbf{k g}^{-1}\right)\end{array}$ & WBC $\left(\mathbf{1 0 3 \mathbf { m m } ^ { - 3 } )}\right.$ & Eosinophil \% & Lymphocyte \% & Monocyte \% & Neutrophils\% \\
\hline Control diet & 0 & $6.53 \pm 0.45^{\mathrm{ab}}$ & $1.51 \pm 0.29^{\mathrm{a}}$ & $14.74 \pm 0.69^{\mathrm{e}}$ & $3.18 \pm 0.24^{\mathrm{a}}$ & $80.58 \pm 0.73^{\mathrm{a}}$ \\
Test diet 1 & 1 & $7.14 \pm 0.73^{\mathrm{ab}}$ & $1.45 \pm 0.21^{\mathrm{ab}}$ & $17.38 \pm 0.61^{\mathrm{d}}$ & $2.80 \pm 0.27^{\mathrm{ab}}$ & $78.37 \pm 0.68^{\mathrm{b}}$ \\
Test diet 2 & 2 & $7.84 \pm 0.40^{\mathrm{a}}$ & $1.35 \pm 0.11^{\mathrm{ab}}$ & $21.25 \pm 0.60^{\mathrm{bc}}$ & $2.41 \pm 0.18^{\mathrm{b}}$ & $74.99 \pm 0.45^{\mathrm{cd}}$ \\
Test diet 3 & 3 & $7.34 \pm 0.44^{\mathrm{ab}}$ & $1.23 \pm 0.16^{\mathrm{ab}}$ & $23.97 \pm 0.86^{\mathrm{a}}$ & $2.16 \pm 0.24^{\mathrm{b}}$ & $72.63 \pm 0.93^{\mathrm{e}}$ \\
Test diet 4 & 4 & $6.87 \pm 0.32^{\mathrm{ab}}$ & $1.14 \pm 0.08^{\mathrm{ab}}$ & $22.28 \pm 0.61^{\mathrm{ab}}$ & $2.69 \pm 0.29^{\mathrm{ab}}$ & $73.89 \pm 0.69^{\mathrm{de}}$ \\
Test diet 5 & 5 & $6.10 \pm 0.64^{\mathrm{b}}$ & $1.04 \pm 0.06^{\mathrm{b}}$ & $20.00 \pm 0.62^{\mathrm{c}}$ & $2.79 \pm 0.22^{\mathrm{b}}$ & $76.18 \pm 0.35^{\mathrm{c}}$ \\
\hline
\end{tabular}

$\mathrm{WBC}=$ White Blood Cells. Means in columns having dissimilar superscripts are statistically dissimilar at $\mathrm{p}<0.05$. Data are means of triplicates.

Table 4. Carcass composition of $L$. rohita fingerlings fed with probiotics supplemented linseed by-product based diet.

\begin{tabular}{ccccccccc}
\hline Diets & $\begin{array}{c}\text { Probiotics Level } \\
\left(\mathbf{g} / \mathbf{k g}^{-1}\right)\end{array}$ & $\begin{array}{c}\text { Crude } \\
\text { Protein }\end{array}$ & $\begin{array}{c}\text { Crude } \\
\text { Fat }\end{array}$ & $\begin{array}{c}\text { Gross Energy } \\
(\mathbf{k c a l} / \mathbf{g})\end{array}$ & Ash & $\begin{array}{c}\text { Crude } \\
\text { Fibre }\end{array}$ & Carbohydrates & Moisture \\
\hline Control diet & 0 & $13.63 \pm 0.61^{\mathrm{cd}}$ & $6.33 \pm 0.39^{\mathrm{bc}}$ & $1.21 \pm 0.20^{\mathrm{c}}$ & $5.43 \pm 0.23^{\mathrm{a}}$ & $1.13 \pm 0.09^{\mathrm{a}}$ & $2.37 \pm 0.19^{\mathrm{a}}$ & $69.90 \pm 0.57^{\mathrm{a}}$ \\
Test diet 1 & 1 & $17.01 \pm 0.75^{\mathrm{ab}}$ & $7.43 \pm 0.63^{\mathrm{abc}}$ & $2.20 \pm 0.26^{\mathrm{a}}$ & $5.56 \pm 0.42^{\mathrm{a}}$ & $1.20 \pm 0.13^{\mathrm{a}}$ & $2.62 \pm 0.19^{\mathrm{a}}$ & $63.97 \pm 1.82^{\mathrm{c}}$ \\
Test diet 2 & 2 & $18.72 \pm 0.56^{\mathrm{a}}$ & $8.80 \pm 0.57^{\mathrm{a}}$ & $2.31 \pm 0.18^{\mathrm{a}}$ & $5.56 \pm 0.42^{\mathrm{a}}$ & $1.06 \pm 0.12^{\mathrm{a}}$ & $2.70 \pm 0.11^{\mathrm{a}}$ & $61.01 \pm 0.42^{\mathrm{d}}$ \\
Test diet 3 & 3 & $17.89 \pm 0.56^{\mathrm{a}}$ & $8.38 \pm 0.38^{\mathrm{abc}}$ & $1.93 \pm 0.22^{\mathrm{ab}}$ & $5.94 \pm 0.22^{\mathrm{a}}$ & $1.25 \pm 0.07^{\mathrm{a}}$ & $2.76 \pm 0.18^{\mathrm{a}}$ & $61.85 \pm 0.37^{\mathrm{cd}}$ \\
Test diet 4 & 4 & $15.33 \pm 0.72^{\mathrm{bc}}$ & $7.73 \pm 0.50^{\mathrm{bc}}$ & $1.57 \pm 0.27^{\mathrm{bc}}$ & $5.34 \pm 0.38^{\mathrm{a}}$ & $1.02 \pm 0.14^{\mathrm{a}}$ & $2.51 \pm 0.18^{\mathrm{a}}$ & $66.51 \pm 0.74^{\mathrm{b}}$ \\
Test diet 5 & 5 & $12.66 \pm 0.60^{\mathrm{d}}$ & $6.24 \pm 0.56^{\mathrm{c}}$ & $1.14 \pm 0.16^{\mathrm{c}}$ & $5.51 \pm 0.25^{\mathrm{a}}$ & $1.20 \pm 0.08^{\mathrm{a}}$ & $2.37 \pm 0.23^{\mathrm{a}}$ & $70.88 \pm 0.54^{\mathrm{a}}$ \\
\hline
\end{tabular}

Means in columns having dissimilar superscripts are statistically dissimilar at $\mathrm{p}<0.05$. Data are means of triplicates. 


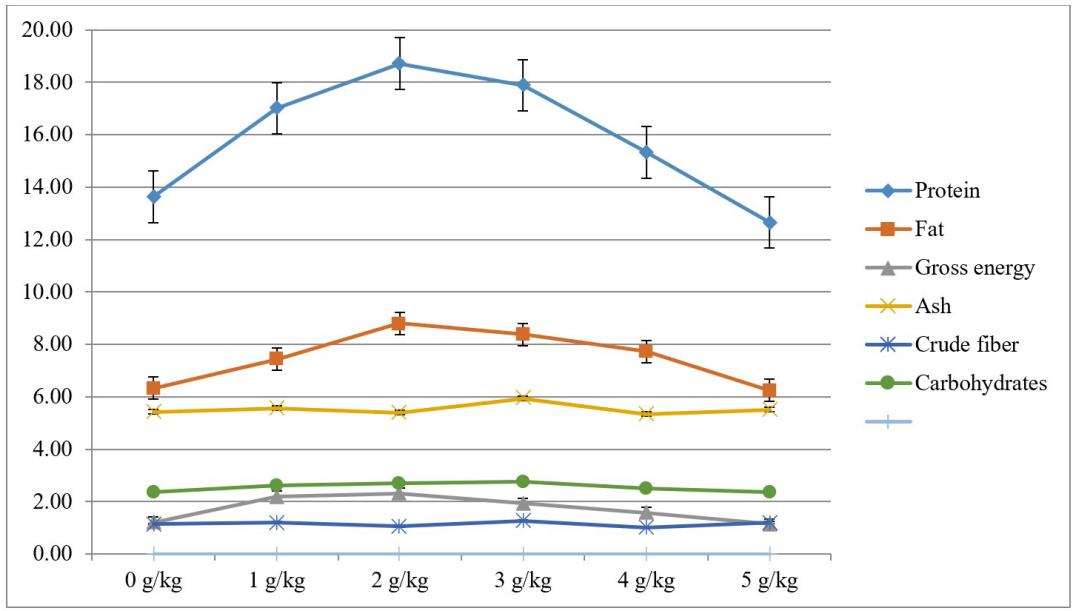

Figure 2. Cumulative carcass parameters of $L$. rohita fingerlings fed with linseed by-product based diet in different groups; T0 to T5.

\section{Discussion}

Fish meal (FM) is an important protein source and contains various nutrients, i.e. fatty acids, essential amino-acids and several attractants (Dawood et al., 2015). Higher cost of FM shifts attention towards the use of plant by-products protein sources. Due to easy availability throughout the year and low cost, plant by-products are going to be utilized as best alternate source of protein (Yuangsoi et al., 2014). It was revealed in many studies that fish fed with probiotics supplemented diet had a positive effect on health, body composition and disease resistance (Lara-Flores et al., 2003).

To monitor fish's health, hamato-immunological parameters can be used as an important indicator to track changes in fish physiology and pathology (Robertson et al., 2000). WBCs play a vital role in immunity and strengthen fish's efficacy to combat infectious diseases (Weiss and Wardrop, 2010). In this analysis, Fingerlings of $L$. rohita showed highest White $\left(7.87 \times 10^{3} \mathrm{~mm}^{-3}\right)$ as well as Red Blood Cells $\left(2.62 \times 10^{6} \mathrm{~mm}^{-3}\right)$, hemoglobin $(7.87 \mathrm{~g}-100 \mathrm{~mL})$ PCV (24.61\%) and platelets (63.85), when fed with $2 \mathrm{~g} / \mathrm{kg}$ of probiotics supplemented LSM based diet. These results showed that the fish hematological parameters improve with increased probiotics concentrations up to $2 \mathrm{~g} / \mathrm{kg}$ of probiotics but decreased with further supplementations. Similar to our results, Hussain et al. (2018) showed that tilapia juveniles indicated the maximum number of Red $\left(3.17 \times 10^{6} \mathrm{~mm}^{-3}\right)$ and White Blood Cells $\left(8.18 \times 10^{3} \mathrm{~mm}^{-3}\right)$ count, fed on diet supplemented with $3 \mathrm{~g} / \mathrm{kg}$ of probiotics. Rajikkannu et al. (2015) reported improvement in RBCs $\left(4.48 \times 10^{6} \mu \mathrm{l}^{-1}\right)$ of common carp and raho fingerlings fed with soybean meal-based diet supplemented at $10^{7} \mathrm{CFUg}^{-1}$ level of probiotics. Soltani et al. (2019) also claimed that, an increase in RBCs was seen in fish fed with probiotics. Diet with probiotics supplementation enhances the immune system by increasing macrophage (Hoseinifar et al., 2018) and WBCs (Korkea-Aho et al., 2012 ) in the blood. L. plantarum supplemented diets for $C$. gariepinus increase the Hb, RBCs, PLT, and PCV compared with control diet (Falaye et al., 2017). Olalusi et al. (2014) observe improvement in WBCs with higher concentrations of probiotics. Contrary to our results, Opiyo et al. (2019) noted that RBC and WBC levels were significantly higher in fish fed on test diet 5 ( $10 \mathrm{~g} / \mathrm{kg}$ of probiotics).

In the present study, the highest concentration of MCHC (33.90\%) and Ht (31.31\%) were recorded in fish fed probiotics supplemented diet 3 ( $3 \mathrm{~g} / \mathrm{kg}$ ). Like our results, Martins et al. (2008) also analyzed improvement in numbers of thrombocytes, lymphocytes and hematocrit $\%$ in 0 . niloticus fingerlings after addition of probiotics. Similarly, Hussain et al. (2018) described that fingerlings fed with (2, 3, and $4 \mathrm{~g} / \mathrm{kg}$ levels) probiotics addition had highest values of hemoglobin in contrast to fish that were fed with control diet. In 0 . niloticus fingerlings fed on diets having Bacillus subtilis and B. cereus, there was an increase in nutrient retention, resulting in improved body composition (Mello et al., 2013). While Salinas et al. (2008) documented that by using two specific strains of bacteria, such as Lactis delbrueckii and B. subtilis, had better influence on blood cell counts than a probiotic mono-strain and found higher PLT count when thaila fed on $3 \mathrm{~g} / \mathrm{kg}$ of probiotics supplemented diet and lowest concentration of $\mathrm{MCH}(37.8 \mathrm{pg})$ in fish was noted when fed on test diet 1 ( $1 \mathrm{~g} / \mathrm{kg}$ probiotics level). Fish fed on control diet (without probiotics) had lowest Ht level (24.69\%). Rajikkannu et al. (2015) reported significant improvement in $\mathrm{Hb}$ in $\mathrm{L}$. rohita fed $10^{7} \mathrm{CFUg}^{-1}$ level of probiotics. Contrary to our results, higher hemoglobin was found in thaila fed with $3 \%(0.3 \mathrm{~g} / \mathrm{kg})$ of probiotics supplemented plant meal based diet (Krishnaveni et al., 2013). When fish juveniles fed on a diet having live B. subtilis as well as Saccharomyces cerevisiae and dead S. cerevisiae, showed significant $(\mathrm{P}<0.05)$ improvement in the hematocrit level when compared to fish fed on the control diet (Firouzbakhsh et al., 2011). Rajikkannu et al. (2015) also discussed statistical improvements in Ht in raho fed $10^{7} \mathrm{CFUg}^{-1}$ level of probiotics. Contrary to our results, Dias et al. (2012) claimed that probiotics supplemented groups' hematocrit values showed a significant decrease compared with the control group. Our research indicated 
that the highest MCV (167.67fl) was noticed in fish fed on test diet 4 ( $4 \mathrm{~g} / \mathrm{kg}$ probiotics) as compared to other diets. Contrary to the present study, the highest MCV in fish fed at $3 \%(0.3 \mathrm{~g} / \mathrm{kg}$ of probiotics $)$ based diet was recorded (Krishnaveni et al., 2013). Therefore in the current study, enhancement in hematological indices of the fingerlings fed probiotic supplemented diets indicates the positive role of probiotics in fish body. Variations in these different studies are may be due to different probiotic strains, feed ingredients, lab conditions or feed preparation methods.

Results showed that the carcass composition improved with the addition of probiotics. In present study maximum crude protein (18.72\%), crude fat (8.80\%) and gross energy $(2.31 \mathrm{kcal} / \mathrm{g})$ contents were found in fish fed test diet 2 , while minimum crude protein (12.66\%), gross energy ( $1.14 \mathrm{kcal} / \mathrm{g}$ ) and crude fat (6.24\%) were analyzed in fingerlings fed with test diet 5 ( $5 \mathrm{~g} / \mathrm{kg}$ of probiotics). Results close to present work were described by Hussain et al. (2018). They found highest level of gross energy $(1.94 \mathrm{kcal} / \mathrm{g})$ in fingerlings fed on diet supplemented with $2 \mathrm{~g} / \mathrm{kg}$ probiotics, while maximum crude fat (10\%) and protein (17\%) were observed in the fingerlings fed on test diet 3 ( $3 \mathrm{~g} / \mathrm{kg}$ probiotics). But there was a decline on higher levels in the absorption of nutrients in the fish body fed on canola meal based diets. In comparison, higher fat (30\%) and protein contents (15\%) were recorded in common carp fingerlings fed on $1 \mathrm{~g} / \mathrm{kg}$ probiotic supplement (Mazurkiewicz et al., 2005). Improved body composition (18\% lipid and $48 \%$ protein) of $C$. carpio fingerlings was discussed when they fed on probiotics $(0.5 \mathrm{~g} / \mathrm{kg})$ supplemented diet (Dhanaraj et al., 2010). Azarin et al. (2015) described that all supplemented test diets groups had significantly higher crude protein at a $1.2 \times 109$ CFUg-1 level of dietary $B$. licheniformis and B. subtilis compared to control. Highest lipid contents were found when tilapia fed a diet supplemented with probiotics at $10^{7} \mathrm{CFU} / \mathrm{g}$ (Essa et al., 2004). Contrary to present results, fish fed on control diet had higher fat contents than fingerlings fed with an experimental diet (Bagheri et al., 2008).

In present study, maximum carbohydrates concentration $(2.76 \%)$ was presented in fish fed on test diet $3(3 \mathrm{~g} / \mathrm{kg}$ of probiotics) and minimum (2.37\%) in fish supplemented on the control diet. On contrary, Ibrar et al. (2017) described that the carbohydrate content of the control group was substantially higher $(\mathrm{P}<0.05)$ than that of the probiotic G. candidum group. This variation in results could occur due to probiotics type and certain environmental conditions. In the present work, ash content was improved in all diets but was found highest $(5.94 \mathrm{Kcal} / \mathrm{g}$ ) in fish fed on test diet 3 (3 g/kg of probiotics). Sahandi et al. (2017) described that probiotics supplementation increased the ash content and were highest at $3 \times 107 \mathrm{CFU} / \mathrm{g}$ as compared to other diets. Contrary to present findings, Amir et al. (2018) observed the highest ash content in fish fed on control diet compared to probiotics supplemented diet. Ibrar et al. (2017) said that the overall ash content of fingerlings fed on control diet was substantially higher $(\mathrm{P}<0.05)$ relative to the probiotic supplemented diet of fingerlings during experimental trial.

Moisture level was highest (70.88\%) in fish fed on test diet 5 ( $5 \mathrm{~g} / \mathrm{kg}$ of probiotics) in present study. Similar results were also observed by Grisdale-Helland et al. (2008), who found improvement in moisture content due to probiotics supplementation. Contrary to our work, Amir et al. (2018) observed that moisture content was higher in fish fed on a control diet than probiotics supplemented diet. Mirghaed et al. (2018) claimed that fermentable fibre (Vitacel ${ }^{\circledR}$ ), probiotic (PrimaLac ${ }^{\circledR}$ ) and their combination does not affect on the moisture level of the fish body. Contradictions may occur due to certain environmental factors and differences in plant meals.

\section{Conclusion}

The present studies recommended that probiotics supplementation at $1 \mathrm{gkg}^{-1}$ to $5 \mathrm{gkg}^{-1}$ level incorporated in the plant-based diets caused changes in the hematology and carcass composition of fish. The outcome from this work demonstrated that $2 \mathrm{~g} / \mathrm{kg}$ of probiotics supplemented LMB diet is suitable to significantly enhance the hemato-immunity and carcass composition of $L$. rohita fingerlings.

\section{References}

ALIKO, V., QIRJO, M., SULA, E., MORINA, V. and FAGGIO, C., 2018. Antioxidant defense system, immune response and erythron profile modulation in goldfish (Carassius auratus), after acute manganese treatment. Fish $\mathcal{E}$ Shellfish Immunology, vol. 76, pp. 101-109. http://dx.doi.org/10.1016/j.fsi.2018.02.042. PMid:29481848.

ALY, S.M., ABDEL-GALIL AHMED, Y., ABDEL-AZIZ GHAREEB, A. and MOHAMED, M.F., 2008. Studies on Bacillus subtilis and Lactobacillus acidophilus, as potential probiotics, on the immune response and resistance of Tilapia (Oreochromis niloticus) to challenge infections. Fish E Shellfish Immunology, vol. 25, no. 1-2, pp. 128-136. http://dx.doi.org/10.1016/j.fsi.2008.03.013. PMid:18450477.

AMIR, I., ZUBERI, A., IMRAN, M. and ULLAH, S., 2018. Evaluation of yeast and bacterial based probiotics for early rearing of Labeo rohita. Aquaculture Research, vol. 49, no. 12, pp. 3856-3863.

ASSOCIATION OF OFFICIAL ANALYTICAL CHEMISTS - AOAC, 1995. Official methods of analysis. Washington: AOAC, 1094 p. https:// doi.org/10.1111/j.1095-8649.1973.tb04510.x.

AUSTIN, B. and AUSTIN, D.A., 2007. Bacterial Fish Pathogens. Diseases of Farmed and Wild Fish. Chichester: Springer-Praxis Publishing Ltd.

AWAD, E. and AWAAD, A., 2017. Role of medicinal plants on growth performance and immune status in fish. Fish EShellfish Immunology, vol. 67, pp. 40-54. http://dx.doi.org/10.1016/j. fsi.2017.05.034. PMid:28526570.

AZARIN, H., ARAMLI, M.S., IMANPOUR, M.R. and RAJABPOUR, M., 2015. Effect of a probiotic containing Bacillus licheniformis and Bacillus subtilis and ferroin solution on growth performance, body composition and haematological parameters in Kutum (Rutilus frisii kutum) fry. Probiotics and Antimicrobial Proteins, vol. 7, no. 1, pp. 31-37.

BAGHERI, T., HEDAYATI, S.A., YAVARI, V., ALIZADE, M. and FARZANFAR, A., 2008. Growth, survival and gut microbial load of rainbow trout (Onchorhynchus mykiss) fry given diet supplemented with probiotic during the two months of first feeding. Turkish Journal of Fisheries and Aquatic Sciences, vol. 8, no. 1, pp. 43-48. 
BLAXHALL, P.C. and DAISLEY, K.W., 1973. Routine haematological methods for use with fish blood. Journal of Fish Biology, vol. 6, pp. 771-781.

BROWN, B.A., 1980. Hematology: principles and procedures. Philadelphia: Lippincott Williams \& Wilkins, pp. 71-112.

DAWOOD, M.A. and KOSHIO, S., 2016. Recent advances in the role of probiotics and prebiotics in carp aquaculture: a review. Aquaculture (Amsterdam, Netherlands), vol. 454, pp. 243-251.

DAWOOD, M.A.O., KOSHIO, S., ISHIKAWA, M. and YOKOYAMA, S., 2015. Effects of Partial Substitution of Fish Meal by Soybean Meal with or without Heat-Killed Lactobacillus plantarum (LP20) on Growth Performance, Digestibility, and Immune Response of Amberjack, Seriola dumerili Juveniles. BioMed Research International, vol. 5, pp. 514196. doi.org/10.1155/2015/514196.

DEFOIRDT, T., SORGELOOS, P. and BOSSIER, P., 2011. Alternatives to antibiotics for the control of bacterial disease in aquaculture. Current Opinion in Microbiology, vol. 14, no. 3, pp. 251-258.

DHANARAJ, M., HANIFFA, M.A., SINGH, S.A., AROCKIARAJ, A.J., RAMAKRISHANAN, C.M., SEETHARAMAN, S. and ARTHIMANJU, R., 2010. Effect of probiotics on growth performance of koi carp (Cyprinus carpio). Journal of Applied Aquaculture, vol. 22, no. 3 , pp. 202-209. http://dx.doi.org/10.1080/10454438.2010.497739.

DIAS, D.C., FURLANETO, F.P.B., AYROZA, L.M.S., TACHIBANA, L., ROMAGOSA, E. and RANZANI-PAIVA, M.J.T.R., 2012. Probiotic in feeding of juvenile matrinxã (Brycon amazonicus): economic viability. Acta Scientiarum. Animal Sciences, vol. 34, no. 3, pp. 239-243.

ESSA, A.M., MABROUK, A.H. and ZAKI, A.M., 2004. Growth performance of grass carp, Ctenopharyngodon idella and hybrid grass carp fingerlings fed on different types of aquatic plants and artificial diet in concrete basins. Egyptian Journal of Aquatic Research, vol. 30, pp. 341-348.

FALAYE, A.E., EMIKPE, B.O., OGUNDIPE, E.T. and OYEBANJI, V.O., 2017. Effects of dietary supplementation of Lactobacillus Plantarum on survival, hematological profile and histopathology of selected organs of Clarias gariepinus fingerlings. Comparative Clinical Pathology, vol. 26, no. 1, pp. 61-69. http://dx.doi.org/10.1007/ s00580-016-2346-6.

FIROUZBAKHSH, F., NOORI, F., KHALESI, M.K. and JANI-KHALILI, K., 2011. Effects of a probiotic, protexin, on the growth performance and hematological parameters in the Oscar (Astronotus ocellatus) fingerlings. Fish Physiology and Biochemistry, vol. 37, no. 4, pp. 833-842.

FOOD AND AGRICULTURE ORGANIZATION - FAO. 2015. Catla catla (Hamilton, 1822), Cultured Aquatic Species Information Programme. Fisheries and Aquaculture Department.

FOOD AND AGRICULTURE ORGANIZATION - FAO. 2016. The State of World Fisheries and Aquaculture. Contributing to food security and nutrition for all. Rome: FAO.

FULLER AFRC, R., 1989. Probiotics in man and animals. The Journal of Applied Bacteriology, vol. 66, no. 5, pp. 365-378. http://dx.doi. org/10.1111/j.1365-2672.1989.tb05105.x. PMid:2666378.

GOBI, N., VASEEHARAN, B., CHEN, J.C., REKHA, R., VIJAYAKUMAR, S., ANJUGAM, M. and ISWARYA, A., 2018. Dietary supplementation of probiotic Bacillus licheniformis Dahb1 improves growth performance, mucus and serum immune parameters, antioxidant enzyme activity as well as resistance against Aeromonas hydrophila in tilapia (Oreochromis mossambicus). Fish E Shellfish Immunology, vol. 74, pp. 501-508.

GRISDALE-HELLAND, B., HELLAND, S.J. and GATLIN III, D.M., 2008. The effects of dietary supplementation with mannanoligosaccharide, fructooligosaccharide or galactooligosaccharide on the growth and feed utilization of Atlantic salmon (Salmo salar). Aquaculture, vol. 283, no. 1-4, pp. 163-167. http://dx.doi.org/10.1016/j. aquaculture.2008.07.012.

GUARDIOLA, F.A., PORCINO, C., CEREZUELA, R., CUESTA, A., FAGGIO, C. and ESTEBAN, M.A., 2016. Impact of date palm fruits extracts and probiotic enriched diet on antioxidant status, innate immune response and immune-related gene expression of European seabass (Dicentrarchus labrax). Fish \& Shellfish Immunology, vol. 52, pp. 298-308. http://dx.doi.org/10.1016/j.fsi.2016.03.152. PMid:27033470.

HARDY, R.W., 2010. Utilization of plant proteins in fish diets: effects of global demand and supplies of fishmeal. Aquaculture Research, vol. 41, no. 5, pp. 770-776.

HOSEINIFAR, S.H., SUN, Y.Z., WANG, A. and ZHOU, Z., 2018. Probiotics as means of diseases control in aquaculture, a review of current knowledge and future perspectives. Frontiers in Microbiology, vol. 9, pp. 2429. http://dx.doi.org/10.3389/fmicb.2018.02429. PMid:30369918.

HUSSAIN, S., AFZAL, M., SALIM, M., JAVID, A., KHICHI, T., HUSSAIN, M. and RAZA, S., 2011. Apparent digestibility of fish meal, blood meal and meat meal for Labeo rohita fingerlings. Journal of Animal and Plant Sciences, vol. 21, no. 4, pp. 807-811.

HUSSAIN, S.M., AHMAD, N., JAVID, A., SHAHZAD, M.M., HUSSAIN, M. and ARSALAN, M.Z.U.H., 2018. Effects of Phytase and Citric Acid Supplemented Corn Gluten (30\%) Meal Based Diets on the Mineral Digestibility of Cirrhinus mrigala Fingerlings. Turkish Journal of Fisheries and Aquatic Sciences, vol. 18, no. 4, pp. 501-507. http://dx.doi.org/10.4194/1303-2712-v18_4_01.

IBRAR, M., ZUBERI, A., AMIR, I., IMRAN, M. and NOOR, Z., 2017. Effect of probiotic Geotrichum candidum on early rearing of Labeo rohita (Hamilton, 1822). Turkish Journal of Fisheries and Aquatic Sciences, vol. 17, no. 6, pp. 1263-1270.

KALEESWARAN, B., ILAVENIL, S. and RAVIKUMAR, S., 2011. Dietary supplementation with Cynodon dactylon enhances innate immunity and disease resistance of Indian major carp (Catla catla). Fish E'Shellfish Immunology, vol. 31, no. 6, pp. 953-962. http://dx.doi.org/10.1016/j.fsi.2011.08.013. PMid:21888977.

KHAN, A.M., SHAKIR, H.A., KHAN, M.N., ABID, M. and MIRZA, M.R., 2008. Ichthyofaunal survey of some freshwater reservoirs in Punjab. Journal of Animal and Plant Sciences, vol. 18, no. 4, pp. 155-157.

KHAN, M.A., AHMED, I. and ABIDI, S.F., 2004. Effect of ration size on growth, conversion efficiency and body composition of fingerling mrigal, Cirrhinus mrigala (Hamilton). Aquaculture Nutrition, vol. 10, no. 1, pp. 47-53. http://dx.doi.org/10.1046/ j.1365-2095.2003.00279.x.

KORKEA AHO, T.L., PAPADOPOULOU, A., HEIKKINEN, J., VON WRIGHT, A., ADAMS, A., AUSTIN, B. and THOMPSON, K.D., 2012. Pseudomonas M162 confers protection against rainbow trout fry syndrome by stimulating immunity. Journal of Applied Microbiology, vol. 113, no. 1, pp. 24-35.

KRISHNAVENI, R., PALANIVELU, K. and VELAVAN, S., 2013. Effects of probiotics and Spirulina supplementation on haematoimmunological function of Catla catla. International Journal of Research in Fisheries and Aquaculture, vol. 3, no. 4, pp. 176-181.

KUMAR, R., MUKHERJEE, S.C., RANJAN, R. and NAYAK, S.K., 2008. Enhanced innate immune parameters in Labeo rohita (Ham.) following oral administration of Bacillus subtilis. Fish \& Shellfish Immunology, vol. 24, no. 2, pp. 168-172. http://dx.doi. org/10.1016/j.fsi.2007.10.008.

LARA-FLORES, M., OLVERA-NOVOA, M.A., GUZMÁN-MÉNDEZ, B.E. and LÓPEZ-MADRID, W., 2003. Use of the bacteria Streptococcus faecium and Lactobacillus acidophilus, and the yeast Saccharomyces cerevisiae as growth promoters in Nile 
tilapia (Oreochromis niloticus). Aquaculture, vol. 216, no. 1-4, pp. 193-201. http://dx.doi.org/10.1016/S0044-8486(02)00277-6.

LI, F.J., LIN, X., LIN, S.M., CHEN, W.Y. and GUAN, Y., 2016. Effects of dietary fish oil substitution with linseed oil on growth, muscle fatty acid and metabolism of tilapia (Oreochromis niloticus). Aquaculture Nutrition, vol. 22, no. 3, pp. 499-508.

LIU, L., LUO, Y., LIANG, X.F., WANG, W., WU, J. and PAN, J., 2013. Effects of neutral phytase supplementation on biochemical parameters in grass carp, Ctenopharyngodon idellus, and gibel carp, Carassius auratus gibelio, fed different levels of monocalcium phosphate. Journal of the World Aquaculture Society, vol. 44, no. 1, pp. 56-65. http://dx.doi.org/10.1111/jwas.12002.

MARTINS, M.L., MOURIÑO, J.L., AMARAL, G.V., VIEIRA, F.N., DOTTA, G., JATOBÁ, A.M., PEDROTTI, F.S., JERÔNIMO, G.T., BUGLIONENETO, C.C. and PEREIRA JÚNIOR, G., 2008. Haematological changes in Nile tilapia experimentally infected with Enterococcus sp. Brazilian Journal of Biology = Revista Brasileira de Biologia, vol. 68, no. 3, pp. 657-661. http://dx.doi.org/10.1590/S151969842008000300025. PMid:18833489.

MAZURKIEWICZ, J., PRZYBYŁ, A. and MROCZYK, W., 2005. Supplementing the feed of common carp (Cyprinus Carpio) juveniles with the biosaf probiotic. Fisheries and Aquatic Life, vol. 13, no. 2, pp. 171-180.

MELLO, H., MORAES, J.R.E., NIZA, I.G., MORAES, F.R., OZÓRIO, R.O.A., SHIMADA, M.T., ENGRACIA FILHO, J.R. and CLAUDIANO, G.S., 2013. Efeitos benéficos de probióticos no intestino de juvenis de Tilápia-do-Nilo. Pesquisa Veterinária Brasileira, vol. 33, no. 6, pp. 724-730. http://dx.doi.org/10.1590/S0100-736X2013000600006.

MIRGHAED, A.T., YARAHMADI, P., HOSSEINIFAR, S.H., TAHMASEBI, D., GHEISVANDI, N. and GHAEDI, A., 2018. The effects singular or combined administration of fermentable fiber and probiotic on mucosal immune parameters, digestive enzyme activity, gut microbiota and growth performance of Caspian white fish (Rutilus frisii kutum) fingerlings. Fish E Shellfish Immunology, vol. 77, pp. 194-199.

OLALUSI, A.C.I., MOJEKWU, T., ADELEKE, T.A., EDAH, B., ADEJONWO, M.O. and ADEYEMI, Y.B., 2014. Digestive enzymes assay and haematological profile of Clarias gariepinus juveniles fed with probiotics supplemented diets. Advances in Plants \& Agriculture Research, vol. 1, no. 4, pp. 00025. http://dx.doi.org/10.15406/ apar.2014.01.00025.

OPIYO, M.A., JUMBE, J., NGUGI, C.C. and CHARO-KARISA, H., 2019. Different levels of probiotics affect growth, survival and body composition of Nile tilapia (Oreochromis niloticus) cultured in low input ponds. Scientific African, vol. 4, pp. e00103.

PHAM, M.A., LEE, K.J., DANG, T.M., LIM, S.J., KO, G.Y., EO, J. and OH, D.H., 2008. Improved apparent digestibility coefficient of protein and phosphorus by supplementation of microbial phytase in diets containing cottonseed and soybean meal for juvenile olive flounder (Paralichthys olivaceus). Asian-Australasian Journal of Animal Sciences, vol. 21, no. 9, pp. 1367-1375. http://dx.doi. org/10.5713/ajas.2008.80053.

RAJIKKANNU, M., NATARAJAN, N., SANTHANAM, P., DEIVASIGAMANI, B., ILAMATHI, J. and JANANI, S., 2015. Effect of probiotics on the haematological parameters of Indian major carp (Labeo rohita). International Journal of Fisheries and Aquatic Studies, vol. 2, no. 5, pp. 105-109.

REDDY, P.V.G.K., 1999. Genetic resources of Indian major carps. Rome: FAO. FAO Fisheries Technical Paper, no. 387.

REIGH, K.C. and ELLIS, S.C., 1992. Effects of dietary soybean and fish protein ratios on growth and body compositionof red drum (Sciaenops clarkii). Aquaculture (Amsterdam, Netherlands), vol. 104, pp. 279-292.
RIDHA, M.T. and AZAD, I.S., 2016. Effect of autochthonous and commercial probiotic bacteria on growth, persistence, immunity and disease resistance in juvenile and adult Nile tilapia Oreochromis niloticus. Aquaculture Research, vol. 47, no. 9, pp. 2757-2767.

ROBERTSON, P.A.W., O'DOWD, C., BURRELLS, C., WILLIAMS, P. and AUSTIN, B., 2000. Use of Carnobacterium sp. as a probiotic for Atlantic salmon (Salmo salar) and rainbow trout (Oncorhynchus mykiss, Walbaum). Aquaculture, vol. 185, no. 3-4, pp. 235-243. http://dx.doi.org/10.1016/S0044-8486(99)00349-X.

ROWLAND, S.J. and INGRAM, B.A., 1991. Diseases of Australian native fishes. In: M. STEVENS, ed. Fisheries Bulletin 4. Sydney, Australia: NSW Fisheries, pp. 21-23.

ROWLAND, S.J., 1991. Diseases of Australian native freshwater fishes with particular emphasis on the ectoparasitic and fungal diseases of Murray cod (Maccullochella peeli), golden perch (Macquaria ambigua) and silver perch (Bidyanus bidyanus). NSW Fisheries Fisheries Bulletin, vol. 4, pp. 21-23.

SAAD, C.R.B., 1979. Use of full-fat roasted soybeans in practical catfish diet. U.S.A: Auburan University, 30 p. M.S. Thesis.

SAHANDI, J., JAFARYAN, H., SOLTANI, M. and EBRAHIMI, P., 2017. Enhancement of growth performance and hematological changes in rainbow trout (Onchorhynchus mykiss) alevins fed with Bifidobacterium bacteria. Journal of Fisheries, vol. 5, no. 1, pp. 439-444.

SALINAS, I., ABELLI, L., BERTONI, F., PICCHIETTI, S., ROQUE, A., FURONES, D., CUESTA, A., MESEGUER, J. and ESTEBAN, M.A., 2008. Monospecies and multispecies probiotic formulations produce different systemic and local immunostimulatory effects in the gilthead seabream (Sparus aurata). Fish E Shellfish Immunology, vol. 25, no. 1-2, pp. 114-123. http://dx.doi. org/10.1016/j.fsi.2008.03.011. PMid:18442923.

SHAHZAD, M.M., HUSSAIN, S.M., HUSSAIN, M., TARIQ M., AHMED, N., FURQAN, M., KHALID, F. and RAFIQUE, T., 2020. Improvement in overall performance of Catla catla fingerlings fed phytase included low cost plant by products-based diet. Saudi Journal of Biological Sciences, vol. 27, no. 8, pp. 2089-2096. http://dx.doi. org/10.1016/j.sjbs.2020.06.012. PMid:32714033.

SHAHZAD, M.M., RAFIQUE, T., HUSSAIN, S.M., HUSSAIN, Z., ZAHOOR, M.Y., HUSSAIN, M., REHMAN, R.A., AHMAD, N., LIAQUAT, I. and BASHIR, S., 2021. Effect of phytase supplemented Moringa by-products based diets on the performance of Oreochromis niloticus fingerlings. Journal of Animal and Plant Sciences, vol. 31, no. 1, pp. 288-295.

SNEDECOR, G.W. and COCHRAN, W.G., 1991. Statistical methods, second printing since 1950. Marine Policy, vol. 39, pp. 94-100.

SOLTANI, M., PAKZAD, K., TAHERI-MIRGHAED, A., MIRZARGAR, S., SHEKARABI, S.P.H., YOSEFI, P. and SOLEYMANI, N., 2019. Dietary application of the probiotic Lactobacillus plantarum 426951 enhances immune status and growth of rainbow trout (Oncorhynchus mykiss) vaccinated against Yersinia ruckeri. Probiotics and Antimicrobial Proteins, vol. 11, no. 1, pp. 207-219.

SUGITA, H., SHIBUYA, K., SHIMOOKA, H. and DEGUCHI, Y., 1996. Antibacterial abilities of intestinal bacteria in freshwater cultured fish. Aquaculture, vol. 145, no. 1-4, pp. 195-203. http:// dx.doi.org/10.1016/S0044-8486(96)01319-1.

VERSCHUERE, L., ROMBAUT, G., SORGELOOS, P. and VERSTRAETE, W., 2000. Probiotic bacteria as biological control agents in aquaculture. Microbiology and Molecular Biology Reviews, vol. 64, no. 4, pp. 655-671.

WAGNER, G.F., JAWORSKI, E.M. and RADMAN, D.P., 1997. Salmon calcitonin inhibits whole body $\mathrm{Ca} 2+$ uptake in young rainbow 
trout. The Journal of Endocrinology, vol. 155, no. 3, pp. 459-465. http://dx.doi.org/10.1677/joe.0.1550459. PMid:9487991.

WANG, K., ZHOU, Y.J., LIU, H., CHENG, K., MAO, J., WANG, F. and ZOU, H., 2015. Proteomic analysis of protein methylation in the yeast Saccharomyces cerevisiae. Journal of Proteomics, vol. 114, pp. 226-233.

WEDEMEYER, G.A. and YASUTAKE, W., 1977. Clinical methods for the assessment of the effects of environmental stress on fish health. U.S.A: U.S. Dept. of the Interior, Fish and Wildlife Service.

WEISS, D.J. and WARDROP, K.J. (2010). Schalm's Veterinary Haematology. Ames: Wiley-Blackwell, 1232 p.
YUANGSOI, B., KLAHAN, R. and CHAROENWATTANASAK, S., 2014. Partial replacement of protein in soybean meal by moringa seed cake (Moringa oleifera) in bocourti's catfish (Pangasius bocourti). Songklanakarin Journal of Science and Technology, vol.36, pp. 125-135.

ZHOU, Q.C., TAN, B.P., MAI, K.S. and LIU, Y.J., 2004. Apparent digestibility of selected feed ingredients for juvenile cobia Rachycentron canadum. Aquaculture (Amsterdam, Netherlands), vol. 241, no. 1-4, pp. 441-451.

ZHOU, X., TIAN, Z., WANG, Y. and LI, W., 2010. Effect of treatment with probiotics as water additives on tilapia (Oreochromis niloticus) growth performance and immune response. Fish Physiology and Biochemistry, vol. 36, no. 3, pp. 501-509. 